\title{
Preliminary Publications Book 2 from Project on Mineral Resources, Metallogenesis, and Tectonics of Northeast Asia
}

By Sodov Ariunbileg, Gombosuren Badarch, Valentina Belichenko, Nikolai A. Berzin, Gennandiy V. Birul'kin, Alexander N. Bulgatov, Jamba Byamba, Alexey V. Deikunenko, Gunchin Dejidmaa, Yuriy V. V. Davydov, Elimir G. Distanov, Yongsheng Dong, Dangindorjiin Dorjgotov, Sergey I. Dril, Valeriy Yu. Fridovskiy, Ivan V. Gordienko, Gennandiy N. Gamyanin, Ochir Gerel, Ayurzana Gotovsuren, Duk Hwan Hwang, Alexander I. Khanchuk, Boris I. Kim, Anatoliy P. Kochnev, Eugeney A. Korago, Mikhail K. Kos'ko, Alexei V. Kostin, Mikhail I. Kuzmin, Sergey A. Letunov, Jiliang Li, Xujun Li, Galina D. Malceva, V.D. Melnikov, Valeriy M. Nikitin, Warren J. Nokleberg, Alexander A. Obolenskiy, Masatsugu Ogasawara, Demberel Orolmaa, Vladimir S. Oxman, Leonid M. Parfenov, Ludmila I. Popeko, Nikolay V. Popov, Andrei V. Prokopiev, Vladimir V. Ratkin, Sergey M. Rodionov, Sergey N. Rudnev, Zhan V. Seminskiy, Vladimir I. Shpikerman, Eugeney V. Sklyarov, Vitaly I. Sotnikov, Alexander P. Smelov, Alexander V. Spiridonov, Vitaly A. Stepanov, Valeriy V. Stogniy, Sadahisa Sudo, Fengyue Sun, Jiapeng Sun, Weizhi Sun, Valeriy M. Supletsov, Oleg I. Suprunenko, Vladimir F. Timofeev, Onongin Tomurtogoo, Felix F. Tret'yakov, Oleg A. Tyan, Valery A. Vernikovsky, Valeriy G. Vetluzhskikh, Alexander G. Vladimirov, Koji Wakita, Aihua Xi, Yakov V. Yakovlev, Hongquan Yan, Mao Ye, Alexander N. Zedgenizov, Vladimir I. Zhizhin, Nikolay N. Zinchuk, and Lydia M. Zorina.

Scientific Editors: Warren J. Nokleberg, Robert J. Miller, Vera V. Naumova, Alexander I. Khanchuk, Leonid M. Parfenov, Mikhail I. Kuzmin, Tatiana M. Bounaeva, Alexander A. Obolenskiy, Sergey M. Rodionov, Zhan V. Seminskiy, and Michael F. Diggles.

\section{Open-File Report 03-203, version 1.0}

\section{3}

Prepared in Collaboration with Russian Academy of Sciences, Mongolian Academy of Sciences, Jilin University (Changchun Branch), Korean Institute of Geology, Mining, and Materials, and Geological Survey of Japan/AIST.

This report is preliminary and has not been reviewed for conformity with U.S. Geological Survey (USGS) editorial standards or with the North American Stratigraphic Code. Any use of trade, firm, or product names is for descriptive purposes only and does not imply endorsement by the U.S. Government.

\section{U.S. DEPARTMENT OF THE INTERIOR U.S. GEOLOGICAL SURVEY}




\section{INTRODUCTION}

This document describes the digital files on this CD-ROM report that consists of summary major compilations and syntheses accomplished in the six-year project through April 2003 for the study on the Mineral Resources, Metdlogenesis, and Tectonics of Northeast Asia (Eastern and Southern Siberia, Mongolia, Northeastem China, South Korea, and Japan). The CDROM report is for sale by U.S. Geological Survey, Information Services, ESIC Open-File Reports, PO Box 25286, Denver, CO 80225 (Telephone 888-ASK-USGS).

\section{ORGANIZATION OF CD-ROM}

At the root (base level) of this CD-ROM are the 1_README.TXT file and this documentation (OF03-203.doc and OF03-203.pdf). The materials on the CD-ROM, including maps, tables, and articles, are stored in the following directories under the indicated file names. Articles and tables are in Word 6 format (*.DOC) and in Adobe Acrobat Reader format (*.PDF). Maps are in Adobe Acrobat Reader format (*.PDF). Plain-text files are in ASCII (*.TXT). This CD-ROM contains the following directories.

Acrobat. This directory contains Adobe Acrobat Reader installation programs for Windows and Macintosh computers. After installing this program, the files in PDF (*.pdf) format (text, figures, and maps) can be viewed and printed.

GEODYNAM. This directory contains the NE Asia Geodynamics Map (5 M scale), introduction, and explanation.

GEOGMAP. This directory contains the NE Asia Geographic Base Map (5 M scale). The map is provided in Adobe Illustrator, Corel Draw 7, and Adobe Acrobat Reacer (PDF) formats.

METBELTS. This directory contains the NE Asia Lode Mineral Deposit and Placer District Map (7.5 M scale), and a series of $12 \mathrm{NE}$ Asia Metallogenic Belt Maps (15 M scale) on three sheets, an introduction, and a summary metallogenic belt table.

MINDEP. This directory contains summary tables of NE Asia lode mineral deposits and placer districts, and an introductory manuscript article.

MINMOD. This directory contains descriptions of mineral deposit models with references for NE Asia

PROJMAT. This directory contains NE Asia project materials, including the project emblem, and pamphlets for NE Asia and previous projects.

\section{CONTENTS OF DIRECTORIES ON CD-ROM}

\begin{tabular}{|c|c|}
\hline Directory & File or S ubdirectory Names (Alphabetical Order) \\
\hline Acrobat & $\begin{array}{l}\text { Directories Mac and PC containing Adobe Acrobat Reader } 5.0 \text { installation } \\
\text { programs. }\end{array}$ \\
\hline GEODYMAP & \begin{tabular}{|c|c|} 
NE Asia Geodynamics Map - Sheet & .pdf \\
NE Asia Geodynamics Map - Sheet 2. & pdf \\
\end{tabular} \\
\hline GEOGMAP & $\begin{array}{l}\text { Geographic Map Text doc and .pdf } \\
\text { Geographic Map.ddr., .ai, and .pdf } \\
\end{array}$ \\
\hline METBELTS & $\begin{array}{l}\text { Introduction.doc and .pdf } \\
\text { Metallogenic Belt Table.doc and.pdf. } \\
\text { NE Asia Lode Mineral Deposit and Placer District Map - Sheet 1.pdf } \\
\text { NE Asia Metallogenic Belt Maps - Sheet 2, Sheet 3, and Sheet 4.pdf } \\
\end{array}$ \\
\hline MINDEP & $\begin{array}{l}\text { Introduction. doc and pdf } \\
\text { Lode Deposits. doc and pdf } \\
\text { Placer Districts. doc and pdf }\end{array}$ \\
\hline MINMOD & NE Asia Mineral Deposit Models. doc and pdf \\
\hline PROJMAT & $\begin{array}{l}\text { NE Asia Project Emblem.pdf } \\
\text { NE Asia Project Pamphlet.pd } \\
\text { Project Area Index Map.pdf } \\
\text { RFE-Ak-Can CordProject Pamphlet.pd }\end{array}$ \\
\hline
\end{tabular}




\section{SYSTEM REQUIREMENTS}

The data and text on this CD-ROM require either a UNIX® system-based or Linux ${ }^{\circledR}$ workstation, Macintosh ${ }^{\circledR}$ or compatible computer, or an IBM ${ }^{\circledR}$ or compatible personal computer, all equipped with a CDROM drive and a color monitor that can display 256 colors (16.7 million recommended). To use this CDROM, a PC should have: Intel ${ }^{\circledR}$ Pentium ${ }^{\circledR}$ or equivalent processor, Microsoft ${ }^{\circledR}$ Windows $\AA 95$ OSR 2.0, Windows 98 SE, Windows Millennium, Windows NT® 4.0 with Service Pack 5, Windows 2000, or Windows XP, and $64 \mathrm{MB}$ of RAM. To use this CDROM, a Macintosh should have a PowerPC® processor, Mac OS software version 8.6, 9.0.4, 9.1, 9.2, or OS X; some features of Acrobat 5 may not be available for OS 8.6 and OS X due to OS limitations, and $64 \mathrm{MB}$ of RAM. Almost any UNIX system-based or Linux workstation can read these files.

On any platforms, you will need Adobe $($ ) Acrobat ${ }^{\circledR}$ Reader 5.0 or higher (5.0.5 and 5.1 included on this disk for Macintosh and Windows) or other software that can translate PDF files.

\section{PORTABLE DOCUMENT FORMAT (PDF) FILES}

This CD-ROM contains Portable Document Format (PDF) files for viewing and searching documents. The Acrobat directory contains installers for Adobe Acrobat Reader 5.0.5 and 5.1 for both Windows (PC directory) and Macintosh (Mac directory). The installers are provided on this disc, or can be downloaded as the latest version of Adobe Acrobat Reader, free, via the Internet from the Adobe homepage on the World-Wide Web at http://www.adobe.com/. In order to view PDF files you will need a reacer that can translate PDF files. This CD-ROM contains a full-text index (INDEX.PDX and associated files in the INDEX directory) that is for use in searching the PDF files for words or sets of words using the search tool in Acrobat Reader.

\section{DISCLAIMERS}

This report is preliminary and has not been reviewed for conformity with U.S. Geological Survey (USGS) editorial standards or with the North American Stratigraphic Code. Any use of trace, firm, or product names is for descriptive purposes only and does not imply endorsement by the U.S. Government.

This Compact Disc-Read Only Memory (CDROM) publication was prepared by an agency of the United States Government. Neither the United States Government nor any agency thereof, nor any of their employees, makes any warranty, expressed or implied, or assumes any legal liability or responsibility for the accuracy, completeness, or usefulness of any information, apparatus, product, or process disclosed in this report, or represents that its use would not infringe privately owned rights. Reference therein to any specific commercial prodict, process, or service by trace name, tracemark, manufacturer, or otherwise does not necessarily constitute or imply its endorsement, recommendation, or favoring by the United States Government or any agency thereof.

Although all data and software published on this CD-ROM have been used by the USGS, no warranty, expressed or implied, is made by the USGS as to the accuracy of the data and related materials and (or) the functioning of the software. The act of distribution shall not constitute any such warranty, and no responsibility is assumed by the USGS in the use of this data, software, or related materials.

\section{ASSOCIATED PROJECT}

These materials on this CD-ROM are a summary of major compilations and syntheses accomplished in six-year project. The major scientific goals and benefits of the project are to: (1) provide a comprehensive international data base on the mineral resources of the region that is the first, extensive knowledge available in English; (2) provide major new interpretations of the origin and crustal evolution of mineralizing systems and their host rocks, thereby enabling enhanced, broad-scale tectonic reconstructions and interpretations; and (3) promote trace and scientific and technical exchanges between the North America and Northeast Asia Data from the project are providing sound scientific data and interpretations for commercial firms, governmental agencies, universities, and individuals that are developing new ventures and studes in the project area, and for land-use planning studes that deal with both mineral potential issues. Northeast Asia has vast potential for known and undiscovered mineral deposits; however, little infomation existed in English in the West until publication of products from this project. Consequently, data and interpretations from the project are providing basic knowledge for major scientific, commercial, national, and international endeavours by other interested individuals and groups.

\section{CUSTOMERS AND COLLABORATING AGENCIES}

Customers for this and the prior include: (1) major mining, petroleum, environmental, construction, investment, and information companies, agencies, and organizations, (2) federal and state government agencies; (3) professional organizations; (4) earth science departments at universities; (5) news media; and (6) mineral resource, petroleum, and information company 
consultants. A major international customer is the Commerce Working Group of the Russian-U.S.A. Commission.

The collaborating agencies for the project are the Russian Academy of Sciences, Mongolian Academy of Sciences, Mongolian Technical University, Jilin University, China, the Korean Institute of Geology, Mining, and Materials, the Geological Survey of Japan/AIST, and the U.S. Geological Survey. Other U.S.A. project participants are the Colorado School of Mines, University of Alaska Fairbanks, Stanford University, and the Northwest Mining Association, Spokane, Washington.

\section{STUDY AREA AND PLANNED PRODUCTS}

The study area for the project consists of Eastern and Southern Siberia, Mongolia, Northeastem China, South Korea, and Japan. The area is approximately bounded by $40^{\circ}$ to $82^{\circ} \mathrm{N}$. latitude and $80^{\circ}$ to $146^{\circ} \mathrm{E}$. longitude.

The planned products include: (a) detailed mineral resource tables and location maps with data on about 1,700 lode deposits and about 100 placer districts, based on original, cited references; (b) regional terrane and overlap-assemblage maps and detailed explanations that provide the geologic setting for mineral deposits and metallogenic belts; (c) metallogenic-belt and mineral resource maps and interpretations; and (d) metallogenic and tectonic interpretations, including a four-dimensional time-space model depicting the crustal origin and evolution of mineral deposits. Publications for the project consist of, rapid preliminary reports, such as this report, of new and important regional geologic maps, map explanations, and general mineral resource tables and maps. Project publications are being released in both paper (USGS publications and scientific joumals), digital (floppy disk, CD-ROM, GIS (ARC-View), and Internet/Web) formats. The various resource tables, maps, and interpretative materials are being authored by the international collaborators with the USGS project members serving as co-editors, and as co-authors on some interpretative articles. 


\section{PROJECT CONTACTS}

For additional information about the project, please contact one or more of the following persons.

\begin{tabular}{|c|c|c|}
\hline Name and Country & Address & $\begin{array}{l}\text { Phone Numbers and e-mail } \\
\text { Address }\end{array}$ \\
\hline $\begin{array}{l}\text { Gombosuren Badarch } \\
\text { Mongolia }\end{array}$ & $\begin{array}{l}\text { Geological Institute } \\
\text { Mongolian Academy of Sciences } \\
\text { Enkhtaivan Avenue } 63 \\
\text { Ulaanbaatar, Mongolia } 210351\end{array}$ & $\begin{array}{l}\text { Voice Telephone: 976-1-5-11-35 } \\
\text { FAX: 976-1-32-43-83 } \\
\text { EMAIL: badarch@magicnet.mn }\end{array}$ \\
\hline $\begin{array}{l}\text { Yan Hongquan } \\
\text { Northeast China }\end{array}$ & $\begin{array}{l}\text { Geological Research Institute } \\
\text { Geology Palace, } 6 \text { Xinminzhu Street } \\
\text { Jiling University, Changchung, } \\
\text { China } 130026\end{array}$ & $\begin{array}{l}\text { Voice Telephone: 86-431-8963476 } \\
\text { FAX: 86-431-892-83-27 } \\
\text { EMAIL: yanhongq@public.cc.jl.cn }\end{array}$ \\
\hline $\begin{array}{l}\text { Alexander I. Khanchuk } \\
\text { Russia - Russian Southeast }\end{array}$ & $\begin{array}{l}\text { Director, Far East Geological } \\
\text { Institute } \\
\text { Russia Academy of Sciences } \\
\text { Prospect 100-letya } 159 \\
\text { Vladvostok-22, Russia } 690022\end{array}$ & $\begin{array}{l}\text { Voice Telephone: 4232-31-83-23 } \\
\text { FAX: 4232-31-87-76 } \\
\text { EMAIL: director@fegi.ru }\end{array}$ \\
\hline $\begin{array}{l}\text { Duk-Hwan Hwang } \\
\text { South Korea }\end{array}$ & $\begin{array}{l}\text { Korea Institute of Geology, Mining, } \\
\text { and Materials } \\
\text { 30, Kajung-dong, Yuson-ku } \\
\text { Taejon, Korea 305-350 } \\
\end{array}$ & $\begin{array}{l}\text { Voice Telephone: 82-42-868-3092 } \\
\text { FAX: 82-42-861-9720 } \\
\text { EMAIL: dhhwang15@hotmail.com }\end{array}$ \\
\hline $\begin{array}{l}\text { Mikhail Kuzmin } \\
\text { Russia - Southeastem } \\
\text { Siberia }\end{array}$ & $\begin{array}{l}\text { Director, Institute of Geochemistry } \\
\text { Russian Academy of Sciences } \\
\text { Irkutsk, Russia } 664033\end{array}$ & $\begin{array}{l}\text { Voice Telephone: 3952-460-500 } \\
\text { FAX: 3952-464-050 } \\
\text { EMAIL: mikuzmin@igc.irkutsk.su }\end{array}$ \\
\hline $\begin{array}{l}\text { Warren J. Nokleberg } \\
\text { U.S.A. }\end{array}$ & $\begin{array}{l}\text { Western Mineral Resources } \\
\text { U.S. Geological Survey, MS } 901 \\
\text { Menlo Park, California USA } \\
94025 \\
\end{array}$ & $\begin{array}{l}\text { Voice Telephone: 650-329-5732 } \\
\text { FAX: 650-329-5134 } \\
\text { EMAIL: wnokleberg@isdmnl.wr.usgs.gov }\end{array}$ \\
\hline $\begin{array}{l}\text { Alexander A. Obolenskiy } \\
\text { Russia - Southern Siberia }\end{array}$ & $\begin{array}{l}\text { United Institute of Geology } \\
\text { Russian Academy of Sciences } \\
\text { Prospect Academician Koptyug No. } \\
3 \\
\text { Novosibirsk, Russia } 630090\end{array}$ & $\begin{array}{l}\text { Voice Telephone: 3832-33-30-28 } \\
\text { FAX: 3832-35-27-92 } \\
\text { EMAL: obolensk@uiggm.nsk.su }\end{array}$ \\
\hline $\begin{array}{l}\text { Masatsugu Ogasawara } \\
\text { Japan }\end{array}$ & $\begin{array}{l}\text { Geological Survey of Japan/AIST, } \\
\text { Tsukuba Central 7, Tsukuba, 305- } \\
\text { 8567, Japan }\end{array}$ & $\begin{array}{l}\text { Voiœ Telephone: 81-298-61-3854 } \\
\text { FAX: 81-298-61-3742 } \\
\text { EMAIL: masa ogasawara@aist.go.jp }\end{array}$ \\
\hline
\end{tabular}

\section{PROJECT SUMMARIES AVAILABLE ON INTERNET/WEB}

Summary of project on Mineral Resources, Metallogenesis, and Tectonics of Northeast Asia (Eastern and Southern Siberia, Mongolia, Northeastem China, South Korea, and Japan)

http://minerals.er.usgs.gov/wr/projects/minres.shtml

Summary of project on Mineral Deposits, Metallogenesis, and Tectonics of the Russian Far East, Alaska, and the Canadian Cordllera http://minerals.usgs.gov/west/projects/majdeps.pdf

\section{PROJECT PUBLICATIONS AVAILABLE ON INTERNET/WEB}

Preliminary Publications Book 1 From Project on Mineral Resources, Metallogenesis, and Tectonics of Northeast Asia: U.S.G.S. Open-File Report 99-165: http://geopubs.wr.usgs.gov/open-file/of99-165/

Significant Metalliferous and Selected Non-Metalliferous Lode Deposits andPlacer Districts for the Russian Far East, Alaska, and Canadian Cordillera: U.S.G.S. Open-File Report 96-513-B:

http://geopubs. wr. usgs.gov/open-file/of96-513-b/ 
Summary Terrane, Mineral Deposit, and Metallogenic Belt Maps of the Russian Far East, Alaska, and the Canadian Cordillera: U.S.G.S. Open-File Report 98136: http://geopubs. wr. usgs.gov/open-file/of98-136/

Geographic Information Systems (GIS) Compilation of Geophysical, Geologic, and Tectonic Maps for the Circum-North Pacific: U.S. Geological Survey Open-File Report 99-422:

http://geopubs. wr. usgs.gov/open-file/of99-422/

Phanerozoic Tectonic Evolution of the Circum-North Pacific: U.S. Geological Survey Professional Paper 1626:

http://geopubs. wr. usgs.gov/prof-paper/pp1626/

Dynamic Computer Model for the Metallogenesis and Tectonics of the Circum-North Pacific: U.S. Geological Survey Open-File Report 01-161: http://geopubs. wr. usgs.gov/open-file/of01-261/

\section{ACKNOWLEDGEMENTS}

For the preparation of this report, we thank the many geologists who have worked with us for their valuable expertise in each region of Northeast Asia We also thank managers N.L. Dobretsov, L.C. Gundersen, P.P. Heam, K. Johnson, R. Koski, L.P. Leahy, J. Medlin, M. Power, K. Schulz, P. Vikre, and J.N. Weaver for their encouragement and support of the project. We thank Russian interpreters Tatiana Bounaeva and Elena Koltunova for their skill and assistance during long and complex scientific dialogues, and for translation of complex geologic descriptions and references. We thank Vladmir Berger and Reimar Seltman for their constructive reviews. 